\title{
MULTILOCUS GENOTYPING OF CRYPTOSPORIDIUM HOMINIS ASSOCIATED WITH DIARRHEA OUTBREAK IN A DAY CARE UNIT IN SÃO PAULO
}

Elenice Messias do Nascimento Gonçalves, Alexandre J. da Silva, Maria Bernadete de Paula Eduardo, Iaiko Horroiva Uemura, Iaci N. S. Moura, Vera L. Pagliusi Castilho, and Carlos Eduardo Pereira Corbett

Gonçalves EM do N, da Silva AJ, Eduardo MB de P, Uemura IH, Moura INS, Castilho VLP et al. Multilocus genotyping of Cryptosporidium hominis associated with diarrhea outbreak in a day care unit in São Paulo. Clinics. 2006;61(2):119-26.

A number of species of Cryptosporidium are associated with diarrhea worldwide. Little data exists regarding the genotypes and species of Cryptosporidium associated with cases of infections in Brazil.

PURPOSE: In the present study, we ascertained by molecular methods the species and the genotype of Cryptosporidium sp from a diarrhea outbreak diagnosed in a day care at the Hospital Clínicas, São Paulo University Medical School.

MATERIALS AND METHODS: Specific identification and typing of the isolates associated with the outbreak was done by DNA sequencing analysis of fragments amplified by polymerase chain reaction (PCR) from 3 different Cryptosporidium loci: the SSUrRNA coding region, the Cryptosporidium oocyst wall protein (COWP) gene, and the microsatellite locus 1 (ML1), a tandem GAG-trinucleotide repeat containing substitutions that differentiate the genotypes of Cryptosporidium parvum and Cryptosporidium hominis.

RESULTS: A total of 29 positive samples from the outbreak were studied by the molecular methods described. Our study revealed the presence of a single genotype of Cryptosporidium hominis in all samples.

CONCLUSION: The molecular analysis reinforced the hypothesis that the transmission of Cryptosporidium hominis during the period the samples were collected occurred in an outbreak pattern, possibly by person-to-person contact through the fecal-oral route. As far as we know, this is the first time that molecular tools have been used to identify the species and the genotype of isolates showing the presence of the ML1 genotype in samples from Brazilian patients.

KEYWORDS: Diarrhea. Cryptosporidium hominis. Parasite. Intestine. Brazil.

\section{INTRODUCTION}

Cryptosporidium $\mathrm{sp}$ is a coccidian genus belonging to the phylum apicomplexa. ${ }^{1}$ This genus includes at least 6 species knowingly associated with intestinal disease in humans that include Cryptosporidium hominis, Cryptosporidium parvum, Cryptosporidium felis, Cryptosporidium meleagridis, Cryptosporidium canis, and Cryptosporidium muris. ${ }^{2-6}$ Cryptosporidium hominis and $C$. parvum are the two most prevalent species causing human

Hospital das Clínicas, São Paulo University Medical School.

Email: ccorbett@usp.br

Received for publication on December 06, 2005.

Accepted for publication on February 16, 2006. disease, associated with both outbreaks and sporadic cases. ${ }^{6,7}$ The other species have been associated only with sporadic cases in immunocompromized persons, but also in individuals not showing signs of immunodeficiency. ${ }^{7,8}$

Cryptosporidiosis may be transmitted directly through person-to-person or person-to-animal contact, or through water or food contaminated by symptomatic or asymptomatic human or animal carriers passing Cryptosporidium oocysts. ${ }^{69-15}$ Massive outbreaks may occur when oocysts end up in water reservoirs serving highly populated communities, such as in the cryptosporidiosis outbreak in the city of Milwaukee, WI, USA, in 1993. ${ }^{16-18}$ Serological surveys conducted worldwide, including in Brazil, have shown the presence of anti-Cryptosporidium antibodies in a large number 
of children living in slums and in infants less than 1 year old living in rural areas. ${ }^{19-21}$ This suggests that exposure to Cryptosporidium oocysts is more frequent in individuals living under inadequate sanitation conditions. Studies conducted in different regions of Brazil have shown that Cryptosporidium sp is associated with symptomatic intestinal disease in HIV infected individuals and in children suffering of acute diarrhea, including those attending day care. ${ }^{22-28}$ Environmental contamination with Cryptosporidium oocysts has been observed in rivers and public water reservoirs serving different regions in Sao Paulo. ${ }^{29-32}$ Nevertheless, no massive cryptosporidiosis outbreaks associated with consumption of water in these regions have been reported. In the state of São Paulo, data gathered on waterborne and foodborne epidemics reported to the Center of Epidemiological Vigilance (CVE) indicated that 10 outbreaks of cryptosporidiosis took place within the period of 1995 to 2003. ${ }^{33}$ In the present study, we used molecular methods to identify the species and the genotype of Cryptosporidium associated with an outbreak that occurred between March and May, 2001, which involved children attending day care at the Hospital das Clínicas, the teaching hospital of the São Paulo University Medical College.

\section{MATERIALS AND METHODS}

\section{Study Site}

Hospital das Clínicas is a 3,271- bed hospital employing 9,888 health care providers, serving patients referred from the Public Health System, and a number of patients referred from private health care providers. The hospital manages a day care center to serve its workers, enrolling children from 4 months to 4 years of age. This center enrolls children based on age or child development, separating them into 7 groups: Nursery I and II (N I and N II) with 46 and 59 children; Mini Group I and II (MG I and MG II) with 41 and 49 children and Toddlers I, II, and III (T I, T II, and T III) with 53, 45, and 35 children respectively.

Stool samples from 224 of the 328 children (68.3\%) attending this day care were collected during the outbreak period in March and May, 2001. The stool samples were processed by concentration methods for ova and parasite (O\&P) examination ${ }^{34-36}$; smears were stained with Kinyoun's modified acid-fast stain for identification of Cryptosporidium sp. ${ }^{37}$ One part of the selected positive samples was mixed with 3 parts of $2.5 \%$ of potassium dichromate and kept at $4^{\circ} \mathrm{C}$ until DNA extraction was performed for molecular analysis.

DNA was extracted from aliquots of approximately 300 $\mu \mathrm{l}$ of each stool specimen using a modification of the
FastDNA $^{\circledR}$ method (Q-Biogene, Carlsbad, CA.) as previously described..$^{38}$ The extracted DNA samples were stored at $4^{\circ} \mathrm{C}$ and used for polymerase chain reaction (PCR) amplification.

\section{PCR Amplification}

A PCR was performed to amplify fragments from 3 different loci of the Cryptosporidium sp genome, ie, $18 \mathrm{~S}$ rRNA, COWP, and microsatellite locus 1 (ML1), following the procedures described below. The PCR products were analyzed by electrophoresis on 2\% SeaKem GTG agarose (Cat. No. 50074, FMC Bioproducts, Rockland, Maine), stained with ethidium bromide and visualized on an ultraviolet transilluminator.

\section{Amplification of a fragment from the SSUrRNA coding region}

The primer pair named CPBDIAGF/CPBDIAGR that produces fragments of 435,438 , and 455 base pairs (bp) from the $C$. parvum, $C$. hominis (formerly know as $C$. parvum genotype 1), and C. felis, respectively, was used for amplification of a variable region of the SSU-rRNA. ${ }^{39}$ Sequencing of this region can distinguish between all the Cryptosporidium species and genotypes described to date. Polymerase chain reactions with these primers were performed as previously described. ${ }^{40}$

\section{Amplification of fragments from the COWP gene}

Two primer pairs, CRY12/CRY14 and CRY15/CRY9, were used to amplify 2 distinct fragments of the COWP gene. The primer pair CRY12/CRY14 was used to amplify a fragment from the C-terminal domain of this gene. Amplification with this primer pair produces fragments that vary from 568 and $571 \mathrm{bp}$ if used on templates from $C$. parvum and $C$. hominis, respectively. The primer pair CRY15/CRY9 was used to amplify a fragment of the Nterminal domain of the same gene. Amplification with these primers produces a DNA fragment of 553 bp from both $C$. parvum and $C$. hominis templates. ${ }^{41}$ Amplifications with primer pairs CRY12/CRY14 and CRY9/CRY15 were performed as described previously, ${ }^{41}$ the only differences being primer concentration (50 pmoles) and reaction cycles (45 times instead of 30).

\section{Amplification of locus ML1}

ML1 was amplified using primers GAGF (5' CTAAAAATGGTGGAGAATATTC 3') and GAGR (5' CAACAAAATCTATATCCTC 3'); the procedure has been 
described elsewhere. ${ }^{42}$ These primers amplify a fragment of approximately $240 \mathrm{bp}$ arranged in tandem GAG repeats. Previous analysis of this locus has revealed polymorphisms that discriminate 2 and 4 genotypes of $C$. hominis and $C$. parvum, respectively.

\section{DNA Sequencing and Analysis}

Amplification products were purified by using the Stratagene PCR purification kit (Cat. No. 400773, Stratagene, La Jolla, Calif.). Sequencing reactions were performed using the Perkin Elmer Big Dye kit (Cat. No. 4303149, PE Biosystems, Foster City, California), and sequence data were obtained by using the Perkin Elmer ABI 3100 automatic DNA sequencer. Sequences were assembled using the program SeqMan II (DNASTAR Inc., Madison, Wisc.). Genotype identification of the ML1 was done by aligning unknowns with master sequences retrieved from GenBank using the program, Clustal X v. $18 .{ }^{43}$ For the other loci analyzed, genotype identification was done by using the GeneStudio suite (GeneStudio Inc., Suwanee, Georgia).

\section{Epidemiologic investigation}

The investigation included interviews with children's mothers and staff as well as analysis of sanitary conditions of the day care center. Children with diarrhea were defined as those with liquid or semi-liquid stools. The risk factors were determined using all patients who were positive for Cryptosporidium as confirmed by PCR and compared with 100 negative-control patients. We considered the same risk factors as those observed by the hospital surveillance group. ${ }^{44}$

We developed an analytical study (retrospective cohort) for Cryptosporidium processing the distribution of frequencies among 2 groups for the qualitative variables, including sex, diarrhea, class, exposure to filtered tap water, use of an earth filter, use of a nursing bottle, use of diapers, ingestion of raw vegetables, and contact among children in the cafeteria and recreation area, using Pearson's chi square test. ${ }^{45}$ Fisher's exact test was used when the expected values were less than 5 . We considered the value $P<0.05$ as statistically significant. Then we calculated the relative risks and their confidence intervals. For ages, we used the Mann-Whitney's nonparametric test, ${ }^{46}$ and $P<0.05$ was considered statistically significant.

\section{RESULTS}

\section{Study Site}

The day care at Hospital das Clinicas had some diarrhea control measures, including dismissal of children with diarrhea, assigning different employees to different functions, such as changing diapers and handling food. Employees conducted such activities in different areas, performing appropriate disposal of diapers and hand washing between procedures. There were distinct restrooms for children and staff, and the water and sewage services used by the day care were the same used by the entire Hospital.

\section{Laboratory Investigation}

Of the 224 children with stool samples analyzed for parasites, 47 (21\%) were negative and 26 (11.6\%) were positive for Giardia lamblia, while 23 (10.3\%) were positive for other parasites, ie, Isospora belli, Trichuris trichiuris, Entamoeba coli, Entamoeba hartmani, Enterobius vermicularis, and Ascaris lumbricoides. For Cryptosporidium sp, 29 (12.9\%) stool samples were positive by microscopic analysis as well as by PCR and were used for analytical epidemiology.

\section{PCR amplification and DNA sequencing analysis for molecular typing}

Cryptosporidium DNA was amplified by PCR from the 29 stool samples using 4 different primer pairs that generate a) 2 independent fragments from the $\mathrm{C}$ and $\mathrm{N}$ terminal domains of the COWP gene (primer pairs CRY12/CRY14 and CRY15/CRY9, respectively); b) 1 fragment from the SSUrRNA coding region (primers CPBDIAGF/ CPBDIAGR); and c) the ML1 (primers GAGF and GAGR).

Genotyping of Cryptosporidium was based on sequencing of all fragments amplified for speciation and for identification of species genotype. The expected fragment size was amplified in all samples using the primers described above. Table 1 summarizes the results obtained from this analysis. Not all samples were amplified with all primers, which might indicate a difference of amplification efficiency among these tools. The only species found in this set was $C$. hominis. Data obtained from the ML1, which can distinguish between the genotypes of $C$. hominis and $C$. parvum, revealed the presence of only 1 genotype, ie, ML1 genotype1, in $45 \%$ of the 29 samples positive for C. hominis, which was subjected to ML1 analysis.

\section{Descriptive and Analytical Epidemiology}

A total of 180 cases met the diarrhea illness definition (general attack rate $=54.9 \%)$ : $19(10.5 \%)$ cases occurred in March, 152 (84\%) in April, and 9 (5.5\%) in May. Of these, 30 cases were from class $\mathrm{N}$ I (attack rate $[\mathrm{AR}]=$ 
Table 1 - Analysis of 29 stool samples positive for Cryptosporidium collected from children attending in the day care at the Clinical Hospital, Sao Paulo Brazil

\begin{tabular}{|c|c|c|c|c|}
\hline Sample & $\begin{array}{l}\text { COWP-C- } \\
\text { terminal }\end{array}$ & $\begin{array}{l}\text { COWP-N- } \\
\text { terminal }\end{array}$ & SSUrRNA & ML1 \\
\hline 1 & C. hominis & C. hominis & C. hominis & G1 \\
\hline 2 & C. hominis & C. hominis & C. hominis & G1 \\
\hline 3 & C. hominis & C. hominis & C. hominis & G1 \\
\hline 4 & C. hominis & C. hominis & C. hominis & G1 \\
\hline 5 & C. hominis & C. hominis & C. hominis & G1 \\
\hline 6 & C. hominis & Negative & C. hominis & G1 \\
\hline 7 & C. hominis & C. hominis & Negative & Negative \\
\hline 8 & C. hominis & C. hominis & C. hominis & Pos-ND \\
\hline 9 & C. hominis & C. hominis & Negative & Negative \\
\hline 10 & C. hominis & C. hominis & C. hominis & G1 \\
\hline 11 & C. hominis & C. hominis & C. hominis & Pos-ND \\
\hline 12 & C. hominis & C. hominis & C. hominis & Pos-ND \\
\hline 13 & C. hominis & C. hominis & C. hominis & Pos-ND \\
\hline 14 & C. hominis & C. hominis & C. hominis & Pos-ND \\
\hline 15 & C. hominis & C. hominis & C. hominis & Pos-ND \\
\hline 16 & C. hominis & C. hominis & C. hominis & Pos-ND \\
\hline 17 & C. hominis & C. hominis & C. hominis & Pos-ND \\
\hline 18 & C. hominis & C. hominis & C. hominis & Pos-ND \\
\hline 19 & C. hominis & C. hominis & C. hominis & G1 \\
\hline 20 & C. hominis & C. hominis & C. hominis & Pos-ND \\
\hline 21 & C. hominis & C. hominis & C. hominis & G1 \\
\hline 22 & C. hominis & C. hominis & C. hominis & G1 \\
\hline 23 & C. hominis & C. hominis & C. hominis & G1 \\
\hline 24 & C. hominis & C. hominis & C. hominis & Negative \\
\hline 25 & C. hominis & C. hominis & C. hominis & G1 \\
\hline 26 & C. hominis & C. hominis & C. hominis & Negative \\
\hline 27 & C. hominis & C. hominis & C. hominis & G1 \\
\hline 28 & C. hominis & C. hominis & Pos-ND & Negative \\
\hline 29 & C. hominis & C. hominis & Pos-ND & Negative \\
\hline
\end{tabular}

Legend: ML1 = microsatellite locus 1; G1-Genotype 1 for the ML1; PosND- positive amplification, with no genotyping data due to PCR amplicons of substandard quality for sequencing analysis; ND-not done due to lack of enough sample for molecular analysis.

65.2\%), 33 from $\mathrm{N}$ II ( $\mathrm{AR}=55.9 \%), 20$ from MG I ( $\mathrm{AR}=$ 48.8\%), $34 \mathrm{MG}$ II $(\mathrm{AR}=69.4 \%), 25 \mathrm{~T} \mathrm{I}(\mathrm{AR}=47.2 \%)$, $28 \mathrm{~T}$ II $(\mathrm{AR}=62.2 \%)$, and $10 \mathrm{~T}$ III $(\mathrm{AR}=28.6 \%)$. We analyzed 164 cases (91.1), and the presence of Cryptosporidium was statistically significant in all classes
$(P=0.001)$, with a higher concentration in MG I (Table 2).We observed no significant association of $C$. hominis with sex, diarrhea, use of a nursing bottle, and contact with other children during recreation (results summarized in Table 3). Children using diapers and drinking water filtered through an earth filter were at higher risk for acquiring $C$. hominis infection compared to the control group $(28.4 \%$ versus $12.5 \% ; P=0.037$ and $39.1 \%$ versus $13.3 \% ; P=$ 0.001 , respectively). However, risk for acquiring $C$. hominis infection was lower for children who used filtered tap water and ingested raw vegetables $(P<0.05)$. For children with $C$. hominis who drank filtered tap water, the frequency was $13.3 \%$ versus $39.1 \%$ compared to children who did not drink filtered tap water. Children who ingested raw vegetables had a $C$. hominis infection frequency of $12.5 \%$ versus $28.4 \%$ for children who did not eat raw vegetables $(P$ $=0.037)$. There was no significant difference in ages between infected and uninfected children $(P=0.316)$.

\section{DISCUSSION}

Cryptosporidium is an ubiquitous parasite found worldwide, Brazil included. ${ }^{19,20,22-30,32,33}$ Despite the number of reports indicating the association of this parasite with diarrhea in different settings and the presence of this parasite in the environment in different regions of this country, only 1 molecular assessment has been previously performed, in clinical samples collected in Fortaleza, Brazil. ${ }^{47}$ We used previously described molecular tools ${ }^{39,41,42}$ to analyze samples collected from children attending a day care at the Hospital das Clínicas, from March to May 2001, during which an outbreak of cryptosporidiosis took place. These tools allowed us to identify that the species associated with all 29 PCR-confirmed cases was $C$. hominis. In addition, a genetic marker that can distinguish among genotypes of $C$. hominis, the ML1 ${ }^{42}$ was also used. The usefulness of the ML1 as a marker to identify $C$. hominis strains with a dis-

Table 2 - Distribution of laboratory positive results for Cryptosporidium confirmed by PCR and collected from children with symptoms of intestinal disease and asymptomatic children by classes - diarrhea outbreak in daycare at the Clinical Hospital, Sao Paulo Brazil, March-May 2001

\begin{tabular}{|c|c|c|c|c|c|c|c|}
\hline & \multicolumn{2}{|c|}{ Children with diarrhea } & \multicolumn{2}{|c|}{ Children asymptomatic } & \multirow[b]{2}{*}{$\begin{array}{l}\text { Children } \\
\text { tested }\end{array}$} & \multirow{2}{*}{$\begin{array}{c}\text { Total } \\
\text { Children } \\
\text { positive }\end{array}$} & \multirow[b]{2}{*}{$\begin{array}{c}\text { Attack } \\
\text { rate }(\%)\end{array}$} \\
\hline & $\begin{array}{l}\text { Children } \\
\text { tested }\end{array}$ & $\begin{array}{l}\text { Children } \\
\text { positive }\end{array}$ & $\begin{array}{c}\text { Children } \\
\text { tested }\end{array}$ & $\begin{array}{l}\text { Children } \\
\text { positive }\end{array}$ & & & \\
\hline N I & 26 & 2 & 6 & 0 & 32 & 2 & 6.3 \\
\hline $\mathrm{N}$ II & 28 & 2 & 9 & 1 & 37 & 3 & 8.1 \\
\hline MG I & 19 & 9 & 6 & 5 & 25 & 14 & 56.0 \\
\hline MG II & 29 & 4 & 5 & 0 & 34 & 4 & 11.8 \\
\hline T I & 24 & 1 & 16 & 0 & 40 & 1 & 2.5 \\
\hline T II & 28 & 3 & 9 & 1 & 37 & 4 & 10.8 \\
\hline T III & 10 & 0 & 9 & 1 & 19 & 1 & 5.3 \\
\hline Total & 164 & 21 & 60 & 8 & 224 & 29 & 12.9 \\
\hline
\end{tabular}


Table 3 - Association between positive results for Cryptosporidium hominis and some risk factors

\begin{tabular}{|c|c|c|c|c|c|c|c|}
\hline & & & Pos & & Pearson's chi & Risk Relative & Confidence Interval \\
\hline & & & No & Yes & square test $(P)$ & & (CI) $95 \%$ \\
\hline Diarrhea & No & $\mathbf{n}$ & 28 & 08 & 0.965 & ND & ND \\
\hline & & $\%$ & 77.8 & 22.2 & & & \\
\hline & Yes & $\mathbf{n}$ & 72 & 21 & & & \\
\hline & & $\%$ & 77.4 & 22.6 & & & \\
\hline Sex & Female & $\mathbf{n}$ & 50 & 10 & 0.140 & ND & ND \\
\hline & & $\%$ & 83.3 & 16.7 & & & \\
\hline & Male & $\mathbf{n}$ & 50 & 19 & & & \\
\hline & & $\%$ & 72.5 & 27.5 & & & \\
\hline Exposure tofiltered tap water & No & $\mathbf{n}$ & 28 & 18 & 0.001 & 0.24 & $0.10-0.57$ \\
\hline & & $\%$ & 60.9 & 39.1 & & & \\
\hline & Yes & $\mathbf{n}$ & 72 & 11 & & & \\
\hline & & $\%$ & 86.7 & 13.3 & & & \\
\hline Exposure toearth filter & No & $\mathbf{n}$ & 72 & 11 & 0.001 & 4.21 & $1.78-10.02$ \\
\hline & & $\%$ & 86.7 & 13.3 & & & \\
\hline & Yes & $\mathbf{n}$ & 28 & 18 & & & \\
\hline & & $\%$ & 60.9 & 39.1 & & & \\
\hline Nursingbottle & No & $\mathbf{n}$ & 70 & 24 & 0.174 & ND & ND \\
\hline & & $\%$ & 74.5 & 25.5 & & & \\
\hline & Yes & $\mathbf{n}$ & 30 & 5 & & & \\
\hline & & $\%$ & 85.7 & 14.3 & & & \\
\hline Diaper & No & $\mathbf{n}$ & 42 & 6 & 0.037 & 2.78 & $1.04-7.41$ \\
\hline & & $\%$ & 87.5 & 12.5 & & & \\
\hline & Yes & $\mathbf{n}$ & 58 & 23 & & & \\
\hline & & $\%$ & 71.6 & 28.4 & & & \\
\hline Ingestionof raw vegetables & No & $\mathbf{n}$ & 58 & 23 & 0.037 & 0.36 & $0.14-0.96$ \\
\hline & & $\%$ & 71.6 & 28.4 & & & \\
\hline & Yes & $\mathbf{n}$ & 42 & 6 & & & \\
\hline & & $\%$ & 87.5 & 12.5 & & & \\
\hline Recreationwith otherchildren & No & $\mathbf{n}$ & 30 & 5 & 0.174 & ND & ND \\
\hline & & $\%$ & 85.7 & 14.3 & & & \\
\hline & Yes & $\mathbf{N}$ & 70 & 24 & & & \\
\hline & & $\%$ & 74.5 & 25.5 & & & \\
\hline
\end{tabular}

tinct biological or clinical profile has not been ascertained. Other authors who have studied the ML1 in C. hominis have not found a large number of genotypes in geographically distinct samples, indicating that this marker may not vary a lot in $C$. hominis. ${ }^{14,42,48}$ Nevertheless, several consistent genotypes of ML1 have been identified in $C$. parvum, which is not as host-specific as $C$. hominis. Our study confirms these findings, since we have only identified one ML1 C. hominis genotype, the ML1 H1, in 45\% of these samples.

The molecular analysis reinforced the hypothesis that the transmission of $C$. hominis during the period the samples were collected occurred in an outbreak pattern, possibly by person-to-person contact through the fecal-oral route. The hypothesis of a diarrhea outbreak in the day care center was confirmed by epidemiological analysis, which showed that
Cryptosporidium infection concentrated mainly in class $\mathrm{MG}$ I, as well as in class MG II, attended by 14- to 27-monthold children who had started to walk, promoting contact with other children. We observed that the exposure to filtered tap water and the ingestion of raw vegetables were not risk factors for acquiring cryptosporidiosis in this group, a fact also observed in a previous study. ${ }^{48}$ As far as we know, this is the first time that molecular tools have been used to identify the species and the genotype of isolates associated with cases of cryptosporidiosis in Brazil. It is also the first report showing the presence of the ML1 genotype in samples from Brazilian patients. The ML1 serves to strengthen the species identification obtained by other molecular markers in C. hominis. However, there are not enough data in the literature ascertaining its usefulness as a molecular epidemiologic tool when used separately. Its function as a marker to 
identify $C$. hominis strains that have distinct biological or clinical profile has not been ascertained either. Our findings support the use of the ML1 as a confirmatory marker for molecular identification of $C$. hominis and support other findings that suggest that ML1 has low variability within this species. ${ }^{14,42,48}$ Because this is a preliminary assessment, it is probably correct to state that this is not the only $C$. hominis genotype associated with cases of cryptosporidiosis in Brazil. This uncertainty indicates the need for more studies of this kind to be conducted in this country.

\section{RESUMO}

Gonçalves EM do N, da Silva AJ, Eduardo MB de P, Uemura IH, Moura INS, Castilho VLP et al. Genotipagem de multilocus de Cryptosporidium hominis associado a surto diarréico em creche de São Paulo. Clinics. 2006;61(2):119-26.

Mundialmente, diferentes espécies de Cryptosporidium estão relacionadas com doenças diarréicas. No Brasil há poucos dados sobre os genótipos das espécies de Cryptosporidium associadas a infecções.

OBJETIVO: No presente estudo, caracterizamos, por métodos moleculares, a espécie e o genótipo de Cryptosporidium sp diagnosticado em surto diarréico ocorrido na creche do Hospital das Clínicas, São Paulo, Brasil.

MATERIAL E MÉTODOS: Identificação específica e tipagem dos isolados associados ao surto foram feitos a partir do seqüenciamento de fragmentos de DNA amplificados por PCR dos seguintes loci: a região que codifica o SSUrRNA, o gene que codifica uma proteína do envoltório dos oocistos de Cryptosporidium (COWP), e o locus de microsatélite ML1, representado por seqüências repetitiva de três nucleotídeos GAG contendo substituições que diferem entre os genótipos de Cryptosporidium parvum e Cryptosporidium hominis.

RESULTADOS: Um total de 29 amostras positivas para Cryptosporidium associadas ao surto diarréico foi analisado com base nos métodos moleculares acima descritos. $\mathrm{O}$ estudo revelou a presença do genótipo ML1 de Cryptosporidium hominis.

DISCUSSÃO: A análise molecular reforçou a hipótese de que a transmissão de Cryptosporidium hominis durante o surto diarréico ocorreu de pessoa a pessoa através da rota fecal oral. Esta é a primeira vez que ferramentas moleculares são utilizadas para identificação de espécies e genótipos de isolados acusando a presença do genótipo ML1 em pacientes brasileiros.

UNITERMOS: Diarréia. Cryptosporidium hominis. Parasita. Intestinal. Brasil.

\section{REFERENCES}

1. Fayer R, Speer CA, Dubey JP. The general biology of Cryptosporidium. In: Fayer R, editor. Cryptosporidium and cryptosporidiosis. Boca Raton, FL: CRC Press; 1997. p. 1-41.

2. Pieniazek NJ, Bornay-Llinares FJ, Slemenda SB, Da Silva AJ, Moura INS, Arrowood MJ, et al. New Cryptosporidium genotypes in HIVinfected persons. Emerg Infect Dis. 1999;5:444-9.

3. Morgan UM, Weber R, Xiao L, Sulaiman I, Thompson RCA, Ndiritu W, et al. Molecular characterization of Cryptosporidium isolates obtained from human immunodeficiency virus-infected individuals living in Switzerland, Kenya, and the United States. J Clin Microbiol. 2000;38:1180-3.

4. Xiao L, Bern C, Limor J, Sulaiman I, Roberts J, Checkley W, et al. Identification of 5 types of Cryptosporidium parasites in children in Lima, Peru. J Infect Diseases. 2001;183:492-7.

5. Fayer R, Trout J, Xiao L, Morgan D, Lai AA, Dubey JP. Cryptosporidium canis n. sp. from domestic dogs. J Parasitol. 2001;87:1415-22.

6. Xiao L, Fayer R, Ryan U, Upton SJ. Cryptosporidium taxonomy: recent advances and implications for public health. Clin Microbiol Rev. 2004; 17:72-97.
7. Fayer R, Morgan U, Upton SJ. Epidemiology of Cryptosporidium: transmission, detection and identification. Int J Parasitol. 2000;30:130522.

8. Bern C, Hernandez B, Lopez MB, Arrowood MJ, De Mérida AM, Klein RE. The contrasting epidemiology of Cyclospora and Cryptosporidium among outpatients in Guatemala. Am J Trop Med Hyg. 2000;63:231-5.

9. Current WL, Reese NC, Ernst WS, Bailey WM, Weinstein WM, Heyman MB. Human cryptosporidiosis in normal and immunodeficient individuals: studies of an outbreak and experimental transmission. $\mathrm{N}$ Engl J Med. 1983;147:824-5.

10. Quiroz ES, Bern C, MacArthur JR, Xiao L, Fletcher M, Arrowood MJ, et al. An outbreak of cryptosporidiosis linked to a foodhandler. J Infect Dis. 2000;181:695-700.

11. Casemore DP, Garder CA, O'Mahony C. Cryptosporidial infection, with special reference to nosocomial transmission of Cryptosporidium parvum: a review. Folia Parasitologica. 1994;41:17-21.

12. Clarck DP. New insights into human cryptosporidiosis. Clin Microbiol Rev. 1999;12:554-63. 
13. Carey CM, Lee H, Trevors JT. Biology, persistence and detection of Cryptosporidium parvum and Cryptosporidium hominis oocyst. Water Res. 2004;38:818-62

14. Chalmers RM, Ferguson C, Cacciò S, Gasser RB, El-Osta YGA, Heijnen $\mathrm{L}$, et al. Direct comparison of selected methods for genetic categorization of Cryptosporidium parvum and Cryptosporidium hominis species. Int J Parasitol. 2005;35:397-410.

15. Hlavsa MC, Watson JC, Beach JB. Cryptosporidiosis surveillanceUnited States 1999-2002. MMWR Surveill Summ. 2005;54:1-8.

16. MacKenzie WR, Schell WL, Blair KA, Addiss DG, Peterson DE, Hoxie NJ, et al. Massive outbreak of waterborne Cyptosporidium infection in Milwaukee, Wisconsin. Recurrence of illness and risk of secondary transmission. Clin Infect Dis. 1995;21:57-62.

17. Addis DG, Pond RS, Remshak M, Juranek DD, Stokes S, Davis JP. Reduction of risk of watery diarrhea with point-of-use water filters during a massive outbreak of water-borne Cryptosporidium infection, Milwaukee, Wisconsin, 1993. Am J Trop Med Hyg. 1996;54:549-53.

18. Cordell RL, Thor PM, Addiss DG, Theurer J, Lichterman R, Ziliak SR, et al. Impact of a massive waterborne cryptosporidiosis outbreak on child care facilities in metropolitan Milwaukee Wisconsin. Pediatr Infect Dis J. 1997:16:639-44.

19. Agnew DG; Lima AAM; Newmam RD; Wuhib T; Moore RD; Guerrant $\mathrm{RL}$, et al. Cryptosporidiosis in northeastern Brazilian children: association with increases diarrhea morbidity. J Infec Dis. 1998;177:75460.

20. Newman RD, Sears C, Moore SR, Nataro JP, Wuhib T, Agnew RL, et al Longitudinal study of Cryptosporidium infection in children in northeastern Brazil. J Infect Dis. 1999;180:167-75.

21. Ungar BLP. Cryptosporidium. In: Mandell GL, et al, editors. Principles and practices of infectious diseases, 5th ed. Philadelphia: Churchill Livingstone; 2000. p. 2903-15.

22. Sauda FC, Zamarioli LA, Ebner Filho W, Mello LB. Prevalence of Cryptosporidium sp and Isospora belli among AIDS patients attending Santos Reference Center for AIDS, São Paulo, Brazil. J Parasitol. 1993;79:454-6.

23. Franco RMB, Cordeiro NS. Giardiose e criptosporidiose em creches no município de Campinas, SP. Revista da Sociedade Brasileira de Medicina Tropical. 1996;29:585-91.

24. Mattiello RMA. Prevalência de enteropatógenos em crianças hospitalizadas por diarréia: aspectos clínicos e epidemiológicos. Dissertação de Mestrado, Faculdade de Medicina de Ribeirão Preto, 1995.

25. Grisi SJFE. Contribuição ao estudo da doença diarréica aguda em crianças com idade inferior a 5 anos e recuperação fecal de Cryptosporidium sp. Tese de Livre Docência, Faculdade de Medicina da USP, 1993.

26. Guizelini E. Pesquisa de oocistos de Cryptosporidium sp nas fezes de pacientes com diarréia, mediante emprego de três técnicas de coloração. São Paulo. Dissertação de Mestrado, Instituto de Ciências Biomédicas da Universidade de São Paulo, 1991.

27. Medeiros MIC, Nemei SN, da Silva P, Capuano DM, Errera MC, Fernandes AS, et al. Etiology of acute diarrhea among children in Ribeirão Preto - SP, Brasil. Revista Instituto Medicina Tropical de São Paulo. 2001:43:21-4.
28. Capuano DM, Okino MHT, Bettini MJCB. Frequency of Cryptosporidium sp and Isospora belli in HIV-seropositive patients in the region of Ribeirao Preto, SP, Brasil. Revista do Instituto Adfolfo Lutz, São Paulo. 2001;60:11-5.

29. Tomps SR. Estudo Epidemiológico da Criptosporidiose e a sua Associação com as Condições de Saneamento Ambiental no Distrito Municipal de Perus, São Paulo. Dissertação de Mestrado, Universidade Mackenzie, 1998.

30. Gamba RC, Ciapina EMP, Espíndola RS, Pacheco A, Pellizari VH. Detection of Cryptosporidium sp oocysts in groundwater for human consumption in Itaquaquecetuba city, S. Paulo-Brazil. Brazilian J of Microbiol. 2000;31:151-3.

31. Franco RMB, Rocha-Eberhardt R, Cantusio Neto R. Occurrence of Cryptosporidium oocysts and Giardia cysts in raw water from the Atibaia River, Campinas, Brazil. Revista do Instituto de Medicina Tropical de São Paulo. 2001;43:109-11.

32. CETESB. Monitoramento ambiental de Cryptosporidium e Giardia em mananciais de abastecimento da rede pública. Base de Dados em Acess, anos de 1999 e 2000. São Paulo, 2002.

33. Divisão de Doenças de Transmissão Hídrica e Alimentar. Surtos de Doenças Transmitidas por Alimentos Dados Estatísticos (Tabelas).InformeNet [online] 2005 [accessad in 2005, June]. Avaliable from URL http:// www.cve.saude.sp.gov.br./htm/hídrica/dta_estat.htm. São Paulo: Centro de Vigilância Epidemiológica; 2005.

34. Hoffman WA, Pons JA, Janer JL. The sedimentation-concentration method in shistomiasis mansoni. Puerto Rico. Journal Public Health. 1934;9:281-98.

35. Faust EC, Sawitz W, Tobie J, Odom V, Peres C, Lincicome DR. Comparative efficiency of various techniques for the diagnosis of protozoa and helminths in feces. J Parasitol. 1939;25:241-62.

36. Rugai E, Mattos T, Brisola AP. Nova técnica para isolar larvas de nematóides das fezes - modificação do método de Baermann. Revista do Instituto Adolfo Lutz. 1954;14:5-8.

37. Moura H, Oliveira LM. Cryptosporidium: parasita de imunocomprometidos. Revista Brasileira de Patologia Clínica. $1985 ; 21: 198-202$

38. Da Silva AJ, Bornay-Llinares FJ, Moura IN, Slemenda SB, Tuttle JL, Pieniazek NJ. Fast and reliable extraction of protozoan parasite DNA from fecal specimens. Mol Diagn. 1999;4:57-64.

39. Johnson DW, Pieniazek NJ, Griffin DW, Misener L, Rose JB. Development of a PCR protocol for sensitive detection of Cryptosporidium oocysts in water samples. Appl Environ Microbiol. 1995;61:3849-55

40. Bornay-Llinares FJ; da Silva AJ; Moura IN; Myjak P; Pietkiewicz H; Kruminis-Lozowska W, et al. Identification of Cryptosporidium felis in a cow by morphologic and molecular methods. Appl Environ Microbiol. 1999;65:1455-8.

41. Spano F, Putignani L, McLauchlin J, Casemore DP, Crisanti A. PCRRFLP analysis of the Cryptosporidium oocyst wall protein (COWP) gene discriminates between $C$. wrairi and $C$. parvum, and between $C$. parvum isolates of human and animal origin. FEMS Microbiol Lett. 1997;150:209-17 
42. Cacciò S, Homan W, Camilli R, Traldi G, Kortbeek T, Pozio E. A microsatellite marker reveals population heterogeneity within human and animal genotypes of Cryptosporidium parvum. Parasitol. 2000;120:237-44.

43. Thompson JD, Gibson TJ, Plewniak F, Jeanmougin F, Higgins DG. The CLUSTAL X-Windows interface: flexible strategies for multiple sequence alignment aided by quality analysis tools. Nucleic Acids Res. 1997;24:4876-82.

44. SEH-HC/FMUSP. Relatório do surto de diarréia da creche anexa ao Hospital. Hospital das Clínicas/Faculdade de Medicina da USP. Documento técnico, São Paulo, Setembro de 2001.

45. Vieira S. Introdução à Bioestatística. Rio de Janeiro: Campus, $3^{\mathrm{a}}$ ed. 1998.
46. Siegel S. and Castellan, NJ. Nonparametric Statistics, 2nd ed. New York: McGraw-Hill: 1988.

47. Brantley RK, Williams KR, Silva TMJ, Sistrom M; Thielman NM, Ward $\mathrm{H}$, et al. AIDS-associated diarrhea and wasting in Northeast Brazil is associated with subtherapeutic plasma levels of antiretroviral medications and with blood bovine and human subtypes of Cryptosporidium parvum. Brazilian J Infect Dis. 2003;7:16-22.

48. Alves M, Xiao L, Sulaiman I, Lal AA, Matos O, Antunes F. Subgenotype analysis of Cryptosporidium isolates from humans, cattle and zoo ruminants in Portugal. J Clin Microbiol. 2003;41:2744-7. 